Paedagogia Christiana

I/27 (20I I) - ISSN 1505-6872

Jarostaw Horowski*

Toruń

\title{
Etyka powinności czy etyka cnoty w przygotowaniu zawodowym nauczycieli?
}

O konieczności uwzględnienia kwestii etycznych w procesie przygotowywania do wykonywania zawodu nauczyciela nie trzeba przekonywać. Dziedzina wychowania jest niezwykle delikatną płaszczyzną działań ze względu na obecność w sytuacjach wychowawczych dzieci, które z racji mniejszego zasobu doświadczeń i gorszego ich rozumienia borykają się $\mathrm{z}$ większymi niż człowiek dorosły trudnościami w identyfikacji własnego dobra oraz możliwościami jego realizacji. To na osobę dorosłą spada zatem odpowiedzialność za ochronę dobra dojrzewającego człowieka. Jednak nie tylko fakt nawiązywania relacji z rozwijającą się osobą stanowi uzasadnienie dla rozważania kwestii etycznych. O wiele istotniejsze jest to, że nauczyciel, podejmując dialog wychowawczy, znacząco wpływa na kształt przyszłego życia młodej osoby - kreśli mapę świata, po którym owa osoba porusza się, oraz proponuje określony sposób wartościowania poszczególnych jego elementów, wskazując nie tylko wartości przedmiotowe, ale również moralne. Specyfika pracy nauczyciela sprawia, że opisuje się ją w kategoriach powołania, a od kandydatów do tego zawodu wymaga się szczególnych predyspozycji ${ }^{1}$.

Współczesna sytuacja społeczno-kulturowa, stanowiąca kontekst dla rozwoju i przygotowania zawodowego przyszłego nauczyciela, nie ułatwia jednak jego rozwoju moralnego, gdyż charakterystyczny dla współczesnej

* Dr Jarosław Horowski, adiunkt na Wydziale Nauk Pedagogicznych Uniwersytetu Mikołaja Kopernika w Toruniu.

${ }^{1}$ Por. J. Dawid, O duszy nauczycielstwa, Warszawa 1948, s. 5-6. 
kultury pluralizm systemów aksjologicznych wywołuje u niejednego dorosłego dezorientację w sytuacji rozwiązywania codziennych problemów, które mają wymiar moralny, albo prowadzi do uznania własnych rozwiązań za kontekstualne i w związku z tym relatywne ${ }^{2}$. Brak pewności w ocenie kwestii moralnych sprawia z kolei, że wielu nauczycieli deklaruje rozdzielenie dydaktyki od wychowania oraz własną kompetencję jedynie w określonym przedmiocie teoretycznym ${ }^{3}$. Wycofują się tym samym z działalności wychowawczej - nie podejmują odpowiedzialności za rozwój osobowości dojrzewającego człowieka, co w praktyce oznacza pozostawienie go pod wpływem osób lub sposobów myślenia kreujących niekoniecznie najlepsze modele życia i działania ${ }^{4}$.

Niniejsze rozważania stanowią próbę odpowiedzi na pytanie, jak przygotowywać przyszłych nauczycieli, aby wprowadzając w tajniki wiedzy teoretycznej, nie bali się podejmowania odpowiedzialności za ogólny rozwój wychowanków. Przedmiotem rozważań będą dwie koncepcje etyki - etyka powinności oraz etyka cnoty, które stanowią alternatywne propozycje, mogące być fundamentem w przygotowaniu zawodowym nauczyciela. Pierwsza z nich w przypadku etyki zawodowej tworzy swoistą deontologię, związaną z działalnością wychowawczą, implikując ideał nauczyciela jako profesjonalisty, spełniającego swoje obowiązki. Druga bliższa jest ujęciu pracy nauczyciela jako powołania, które domaga się nie tylko sumiennego wykonywania określonych zadań, ale także podejmowania działań mających na celu dobro dojrzewającego człowieka, a równocześnie nieobjętych bezpośrednio obowiązkami zawodowymi ${ }^{5}$. Aby odpowiedzieć na postawione powyżej pytanie, należy zatem pokrótce przedstawić obie koncepcje etyczne.

2 Por. A. Bronk, Krajobraz postmodernistyczny, „Ethos” 9 (1996), nr 33-34, s. 84; tenże, Spór o postmodernizm, w: tenże, Zrozumieć świat współczesny, Lublin 1998, s. 47-51; J. Mariański, Młodzież między tradycją a ponowoczesnościa, Lublin 1995, s. 14; F. Fukuyama, Wielki wstrzqs. Natura ludzka a odbudowa porzqdku społecznego, Warszawa 2000, s. 13.

${ }^{3}$ Por. R. Kwaśnica, Wprowadzenie do myślenia o nauczycielu, w: Z. Kwieciński, B. Śliwerski (red.), Pedagogika. Podręcznik akademicki, t. 2, Warszawa 2004, s. 310-311.

${ }^{4}$ Por. H. Kwiatkowska, Pedeutologia, Warszawa 2008, s. 13; tenże, Kształcenie nauczycieli a nowe sposoby uczenia się człowieka, w: H. Kwiatkowska, T. Lewowicki, S. Dylak, Wspótczesność a ksztatcenie nauczycieli, Warszawa 2000, s. 35-36.

${ }^{5}$ Zob. P. Kostyło, Wykluczanie jako problem filozofii edukacji. Komentarz do badań empirycznych, Kraków 2008. Do podjęcia niniejszego tematu skłoniła mnie wskazana praca Piotra Kostyło, w której autor rozważa różne koncepcje etyczne pod kątem przygotowania nauczyciela do zaangażowania w likwidację problemu wykluczania uczniów z dostępu do kultury symbolicznej. Por. J. Horowski, recenzja książki P. Kostyło, Wykluczanie ..., „,Rocznik Andragogiczny" 2008, s. 326-331. 


\section{Etyka powinności jako etyka profesjonalisty}

Zanim określona zostanie specyfika etyki powinności w odniesieniu do zawodu nauczyciela, warto zwrócić uwagę na problemy związane z etyką powinności jako taką. W klasycznej etyce filozoficznej, zbudowanej na systemie arystotelesowsko-tomistycznym, powinność moralna była nierozerwalnie związana z obiektywnym dobrem moralnym ${ }^{6}$. Od czasów Immanuela Kanta pojawiła się jednak inna możliwość rozumienia powinności. $\mathrm{W}$ jego koncepcji powinność, nazwana imperatywem kategorycznym, jest wewnętrznym czynnikiem moralnotwórczym - nie odnosi się zatem u swych źródeł do dóbr zewnętrznych ${ }^{7}$. W praktyce Kant zbudował fundament dla subiektywizmu w etyce. Subiektywizmowi przeciwstawił się Max Scheler, który podjął próbę zbudowania etyki obiektywistycznej - odwołującej się do wartości przedmiotowych. Gruntowne i radykalne wprowadzenie do systemu etycznego zasady wartości odbiło się jednak na stosunku do powinności moralnej. Zdaniem Schelera, obowiązek i wartość wzajemnie się wykluczają ${ }^{8}$. Mówiąc o powinności należy zatem mieć świadomość, że jest ona rozważana jako implikacja obiektywnego dobra albo jako wewnętrzny czynnik kształtujący rzeczywistość ludzkiego czynu. Druga koncepcja, odwołująca się do obecnego w ludzkich przeżyciach poczucia powinności, w praktyce prowadzi do subiektywizmu, gdyż uzależnia powinność jedynie od przeżycia jednostki. W większości potocznych wypowiedzi o powinności moralnej trudno rozpoznać, jaką jej koncepcję ma na myśli autor. Można zatem zgodzić się z uwagą jaką sformułował Alasdair MacIntyre w swoim studium Dziedzictwo cnoty, że „terminy takie jak «cnota», «sprawiedliwość», «pobożność», «obowiązek», a nawet «powinność», w procesie przechodzenia od różnorodności kontekstów, z których się pierwotnie wywodziły, do naszej współczesnej kultury, stały się czymś innym niż były kiedyś" ".

Pojawiające się współcześnie kodeksy etyki zawodowej sąjednak świadectwem, że o powinności mówi się w kontekście obiektywnego dobra moralnego. Systemy ocen, norm i wzorów regulujących postępowanie przedstawicieli określonych grup zawodowych budowane są bowiem nie w oparciu

${ }^{6}$ Por. J. Maritain, Dziewięć wykładów o podstawowych pojęciach filozofii moralnej, Lublin 2001, s. 170-172.

${ }^{7}$ Por. F. Copleston, Historia filozofii, t. VI: Od Wolffa do Kanta, Warszawa 1996, s. 332-376.

${ }^{8}$ Por. K. Wojtyła, Ocena możliwości zbudowania etyki chrześcijańskiej przy założeniach systemu Maxa Schellera, w: tenże, Zagadnienie podmiotu moralności, Lublin 2001, s. 25.

9 A. MacIntyre, Dziedzictwo cnoty. Studium z teorii moralności, Warszawa 1996, s. 37. 
o wewnętrzne przekonania, co należy czynić w danej sytuacji, ale na fundamencie analiz, wskazujących na pozytywne bądź negatywne skutki poszczególnych działań. Takie kodeksy formułuje się na przykład w dziedzinach biznesu $^{10}$, dziennikarstwa ${ }^{11}$ czy pracy socjalnej ${ }^{12}$. Nieco inna jest sytuacja nauczyciela, który z jednej strony posiada określone prawem podstawowe powinności, a z drugiej strony funkcjonuje w ramach większej społeczności zawodowej, budującej swoisty etos i przekazującej dzięki niemu modele zachowań w sytuacjach nieregulowanych odgórnymi przepisami ${ }^{13}$. Można jednak powiedzieć, że deontyczny charakter etosu sprawia, iż stanowi on niepisany kodeks etyki zawodowej, który początkujący nauczyciel przyswaja sobie, uczestnicząc w życiu szkoły.

Etyka powinności, znajdująca odzwierciedlenie przede wszystkim w różnorodnych kodeksach, bardzo dobrze koresponduje ze współczesnym ideałem profesjonalisty. Od profesjonalisty oczekuje się bowiem, że będzie ekspertem w swojej dziedzinie, będzie potrafił przewidywać skutki określonych działań, a podejmując decyzje będzie kierował się dobrem swoich klientów. Ogólnie o profesjonalizmie decyduje jakość działań w odniesieniu do ich przedmiotu. W przypadku zawodu nauczyciela jest to o tyle specyficzne, że ów przedmiot jest drugim podmiotem, a więc współuczestniczy w tworzeniu rzeczywistości wychowawczej. Współcześnie w przypadku zawodu nauczyciela model profesjonalisty buduje się głównie w oparciu o koncepcję rozszerzonego profesjonalizmu nauczycielskiego Erica Hoyle’a, pogłębioną przez Donalda Schöna, który wprowadził do literatury sformułowanie «refleksyjny praktyk». Rozważania nad profesjonalizmem nauczyciela znalazły istotne miejsce w pracach: Davida Trippa, rozwijającego koncepcję, opartą na «profesjonalnym osądzie»; Johna Elliota, kreującego model «nowego profesjonalizmu»; czy Delli Fish, która formułuje koncepcję «profesjonalnego artyzmu» ${ }^{14}$. Nie wnikając w specyfikę każdej z tych koncepcji, należy podkreślić ich przedmiotowy charakter, czyli utożsamienie profesjonalizmu

${ }^{10}$ Zob. np. Kodeks etyki dla przedsiębiorców, http://www.kig.pl/index.php/Kodeksetyki-dla-przedsiebiorcow (pobrano 25.05.2009); M. Rybak, Etyka menadżera - spoteczna odpowiedzialność przedsiębiorstwa, Warszawa 2004.

${ }^{11}$ Zob. np. Kodeks Etyki Dziennikarskiej Stowarzyszenia Dziennikarzy Polskich, Karta etyczna mediów; Dziennikarski kodeks obyczajowy Stowarzyszenia Dziennikarzy RP; Deklaracja zasad Międzynarodowej Federacji Dziennikarzy, http://www.tvp.pl/o-tvp/ komisja-etyki/ (11.05.2009); Z. Sareło, Media w stużbie osoby. Etyka społecznego komunikowania, Toruń 2002.

12 Zob. Kodeks Etyczny Polskiego Towarzystwa Pracowników Socjalnych, http://ptps. ops.pl/kodeks_etyczny.htm (25.05.2009); G. Grzybek, Etyczne podstawy pracy socjalnej, Bielsko-Biała 2007, s. 135-148.

${ }_{13}$ Por. S. Witek, Etos, w: Encyklopedia katolicka, t. 4, Lublin 1995, kol. 1195-1196.

${ }^{14}$ Por. B. Gołębniak, Zmiany edukacji nauczycieli. Wiedza - biegłość - refleksyjność, 
z jakością działań względem przedmiotu. Etyka powinności posiada także orientację przedmiotową. Określa bowiem obowiązki względem przedmiotu, nie wskazując na normy odnoszące się do działającego podmiotu. W świetle etyki powinności dobrym pod względem moralnym nauczycielem jest ten, który sumiennie wypełnia wszystkie zadania względem ucznia, jakie nakłada na niego wykonywany zawód.

Przyglądając się etyce powinności, warto zwrócić uwagę na dwie jej cechy. Po pierwsze, rozdziela ona niejako działalność zawodową oraz sferę życia prywatnego - nie dotyka zatem poglądów ani działań, które ze względu na brak bezpośredniego odniesienia do ucznia określane są jako prywatne. Po drugie, ma ona ograniczony zakres, ponieważ trudno ujać w kodeksie wszystkie sytuacje związane $\mathrm{z}$ działalnością wychowawczą i tym samym opisuje ona moralne problemy wynikające głównie z pracy dydaktycznej.

\section{Etyka cnoty jako etyka powołania}

Etyka cnoty w porównaniu z etyką powinności kładzie dużo większy nacisk na moralną jakość działającego podmiotu ${ }^{15}$. Cnota jest bowiem rozumiana jako moralnie uporządkowana postawa do zrealizowania czynów dobrych w określonej dziedzinie ludzkiego działania i w tym sensie jest ona traktowana jako komponent osobowości człowieka ${ }^{16}$. Mówiąc o etyce cnoty, należy jednak uwzględnić niejasności terminologiczne, pojawiające się analogicznie jak w przypadku pojęcia «powinność». Rozważania o cnocie sięgają starożytności. Usystematyzowana nauka o cnocie znajduje się na przykład w pismach Arystotelesa. W średniowieczu nawiązał do niej św. Tomasz z Akwinu. W XX wieku zaznaczyły się one w dwóch tradycjach filozoficznych. Za sprawą Desire Josepha Merciera w środowiskach katolickich w Europie wrócono do tomistycznej koncepcji cnoty ${ }^{17}$. Refleksję nad

Poznań 1998, s. 114-137; H. Kwiatkowska, Pedeutologia, s. 167-186. Zob. także M. Czerepaniak-Walczak, Aspekty i źródła profesjonalnej refleksji nauczyciela, Torun 1997.

15 Por. J. Górnicka-Kalinowska, Idea sumienia w filozofii moralnej, Warszawa 1999, s. 10 .

16 Por. S. Witek, Cnota, w: Encyklopedia katolicka, t. 3, Lublin 1995, kol. 521.

${ }^{17}$ Por. S. Kunowski, Tomistyczne studia $w$ dziedzinie pedagogiki, w: Pastori et Magistro. Praca zbiorowa dla uczczenia 50-lecia kapłaństwa Ks. Bpa P. Kałwy, Lublin 1966, s. 742; J. Kuchta, Nowe kierunki i dążenia wspótczesnej katolickiej pedagogiki (na tle chaosu we współczesnym wychowaniu), Lwów 1939, s. 77-78; J. Tarnowski, Problem chrześcijańskiej pedagogiki egzystencjalnej, Warszawa 1982, s. 16. W Polsce problem pozytywnej sprawności stanął w centrum pedagogicznych rozważań o. Jacka Woronieckiego OP. Zob. np. J. Woroniecki, Studium nad kardynalnq cnota roztropności, „Kwartalnik Teologiczny Wileński” 1-2 (1923-1924), s. 226-247; tenże, Cnota kardynalna umiarkowania, „Szkoła 
cnotą podjęto również w anglosaskiej etyce, głównie dzięki pracom Alasdair'a MacIntyre'a. Pojęcie «cnoty» w obydwu tradycjach jest jednak inaczej rozumiane. Nurt tomistyczny buduje aretologię w oparciu o założenie obiektywnego charakteru prawdy oraz dobra i na tym fundamencie kreśli najpierw koncepcję cnót kardynalnych: roztropności, sprawiedliwości, umiarkowania i męstwa, a następnie wyprowadza z nich kolejne cnoty. Z kolei Alasdair MacIntyre odrzuca ideę cnót uniwersalnych - sytuuje cnotę w kontekście społecznych potrzeb, nadając jej tym samym charakter relatywny i instrumentalny ${ }^{18}$.

W niniejszych rozważaniach cnota jest rozumiana jako zdolność do realizacji obiektywnego dobra. Takie założenie wymusza chociażby fakt wcześniejszego powiązania powinności z dobrem, któremu przypisano obiektywny charakter. $Z$ przyjętego założenia wynika, że chociaż sam termin «cnota» zdaje się odnosić wyłącznie do podmiotu moralnego działania, opisując go w kategoriach doskonałości moralnej, to w rzeczywistości wskazuje on na problem przedmiotu ludzkich działań. Cnoty są bowiem sprawnościami moralnymi w realizacji moralnego dobra. Sprawności mogą być jednak również wadami, jeżeli zwiększają łatwość realizacji moralnego zła.

Ponieważ cnota, jeżeli rozwinie się w człowieku, stanowi komponent jego osobowości, dlatego etyka cnoty kreśli ideał człowieka, który w swoich działaniach dąży konsekwentnie do realizacji dobra. W przypadku etyki zawodowej jest to ideał człowieka, który nie tyle posiada wytyczne co do zachowań względem klienta, ale roztropnie rozpoznaje, co dla tej osoby jest najlepsze i zgodnie z zasadą sprawiedliwości stara się pomóc podopiecznemu w realizacji owego dobra. Umiejętnie kieruje również swoimi uczuciami, których reakcje porządkują umiarkowanie oraz męstwo. Doskonałość cnoty polega na tym, że ludzkie działania reguluje od wewnątrz, a nie od zewnątrz poprzez szereg nakazów, które nakładane są na człowieka. Z tego względu koresponduje ona $\mathrm{z}$ ujęciem zawodu jako powołania, między innymi w odniesieniu do zawodu nauczyciela. O powołaniu zawodowym można bowiem mówić wówczas, gdy człowiek posiada cechy predestynujące go do wykonywania określonych czynności, a dobro moralne jest przez niego realizowane niezależnie od deontologii zawodowej.

Chrystusowa" 1 (1930), nr 5, s. 227-237; tenże, Cnota wstrzemięźliwości i wychowanie jej, „Szkoła Chrystusowa” 2 (1931), nr 3, s. 97-111; tenże, Cnota kardynalna męstwa. Jej istotne cechy, niedomagania $i$ wychowanie, „Szkoła Chrystusowa” 16 (1938), nr 4, s. 233-243; tenże, Czynnik umystowy w cnotach $i$ wadach, „Szkoła Chrystusowa” 19 (1939), nr 8, s. 65-78; J. Horowski, Paedagogia perennis $w$ dobie postmodernizmu. Wychowawcze koncepcje o. Jacka Woronieckiego a kultura przełomu XX i XXI wieku, Torun 2007.

18 Por. A. MacIntyre, dz. cyt., s. 327-364. 
Omawiając etykę cnoty, warto zwrócić uwagę, że w przeciwieństwie do etyki powinności nie przeprowadza ona granicy między życiem prywatnym oraz pracą zawodową. Nie można bowiem w życiu zawodowym działać w sposób charakterystyczny dla jakiejś cnoty, natomiast w życiu prywatnym cechować się w podobnych działaniach wadami. Nie można również ,wyłączyć” poza godzinami pracy swojej wrażliwości na problemy zawodowe. Konsekwentnie, nauczyciel, który osiagną doskonałość cnoty, nie oddziela pracy dydaktycznej od funkcji wychowawczych, wspierając dojrzewającego człowieka w jego rozwoju.

\section{Profesjonalizm czy powołanie - etyka powinności czy etyka cnoty?}

Po nakreśleniu charakterystyki etyki powinności oraz etyki cnoty można wrócić do postawionego na początku pytania o możliwości wykorzystania każdej z tych koncepcji w przygotowaniu zawodowym nauczyciela. Intuicyjnie skłonni jesteśmy przyznać, iż praca nauczyciela domaga się bardziej etyki cnoty niż etyki powinności. Oddzielenie dydaktyki od wychowania jest bowiem wytyczaniem sztucznej granicy, która w kontaktach nauczyciela z uczniami w rzeczywistości nie istnieje. Kontakty owe prowadzą bowiem do budowania relacji i kształtują wszystkie, obecne w nich podmioty. Uczestnicząc w tych relacjach nie sposób ukryć własnych uczuć, poglądów, nie sposób oddzielić życia prywatnego od zawodowego. Nauczyciel jest zawsze postrzegany przez ucznia całościowo i w związku z tym nie jest w stanie do końca przewidzieć charakteru własnych oddziaływań, a tym bardziej zaplanować go i kontrolować ${ }^{19}$. Mimo że etyka cnoty jawi się jako doskonalsza ze względu na charakter pracy nauczyciela, to odrzucanie etyki powinności wydaje się z kilku względów niewłaściwe.

Po pierwsze, olbrzymią zaletą etyki powinności jest jej przedmiotowy charakter. Wynika ona bowiem z analizy sytuacji wychowawczych oraz możliwych konsekwencji poszczególnych zachowań nauczyciela. Cnota, mimo swojego przedmiotowego aspektu, wskazuje bardziej na wewnętrzne nastawienie nauczyciela, ale ono nie zawsze musi znaleźć wyraz we właściwej postawie względem ucznia. Nauczyciel może przecież pragnąć dobra i jednocześnie wywołać negatywne konsekwencje w życiu dojrzewającego człowieka. Cnota nie daje zatem gwarancji niepopełnienia błędu, analogicznie

19 Por. R. Kwaśnica, dz. cyt., s. 296-297. 
jak działanie «w zgodzie z sumieniem» nie jest gwarancją realizacji dobra, chociaż należy działać, jeżeli sumienie znajduje się w stanie pewności ${ }^{20}$.

Po drugie, nie wszyscy, którzy podejmują pracę nauczyciela, posiadają do niej predyspozycje. Uznanie więc etyki cnoty za jedyną właściwą etykę zawodu nauczyciela byłoby ukrytym postulatem względem nauczycieli, aby charakteryzowali się powołaniem do tej pracy, a w gruncie rzeczy byłoby także utopią w myśleniu. Część nauczycieli to osoby, które podejmują pracę w tym zawodzie, mimo że nie mieli takich zamiarów, a zatem etyka powinności jawi się jako odpowiednie narzędzie $\mathrm{w}$ regulowaniu ich postaw względem uczniów. Niejasna jest ponadto sytuacja początkujących nauczycieli, dla których szczególnie pierwszy okres pracy w szkole jest czasem intensywnego rozwoju, odkrywania nowych sytuacji i budowania własnych postaw względem problemów, z którymi stykają się w pracy zawodowej.

Po trzecie, warto zwrócić uwagę na trudność w przekazie etyki cnoty w ramach uniwersyteckiego wykładu. O ile łatwo wyliczyć podstawowe obowiązki nauczyciela i uzasadnić je dobrem ucznia, to cnota nie jest konsekwencją teoretycznych rozważań. Cnota jest bowiem doskonałością charakteru, czy według nowszej terminologii doskonałością osobowości człowieka $^{21}$, więc jej ukształtowanie zależy od rozwoju rozumu, woli oraz poznawczych i pożądawczych władz zmysłowych. Rozwój cnót wymaga czasu, niekiedy dojrzewania do nich w ciagu całego życia. Teoria przekazywana w ramach uniwersyteckiego wykładu nie będzie więc z pewnością skutkowała doskonałością cnoty u przyszłych nauczycieli.

Jak wynika z prowadzonych analiz, nie jest łatwo odpowiedzieć na pytanie, która $\mathrm{z}$ koncepcji etycznych powinna stać się fundamentem w edukacji nauczycieli w XXI wieku. Problem może zostać jednak rozwiązany, jeżeli spojrzy się na cnotę jako efekt dojrzewania nie tylko «do podjęcia» pracy nauczyciela, ale także «w ramach wykonywania» zawodu nauczyciela.

\section{Moralność powinności i moralność cnoty jako etapy na drodze rozwoju zawodowego nauczyciela}

W dotychczasowych opisach etyka powinności oraz etyka cnoty traktowane były jako propozycje alternatywne. W gruncie rzeczy takie podejście możliwe jest jedynie w ujęciach teoretycznych. Mimo wskazanych różnic

${ }^{20}$ Por. T. Ślipko, Zarys etyki ogólnej, Kraków 2004, s. 380-383.

${ }^{21}$ W myśli współczesnej rezygnuje się z terminu «charakter», zastępując go pojęciem «osobowość». Por. M. Nowak, Charakter w pedagogice - historia i wspótczesność, w: Wychować charakter, Lublin 2005, s. 53. 
powinność i cnota posiadają wiele wspólnego, a związek między nimi uwidacznia się, jeżeli rozważa się je w kontekście przekonania o obiektywnym charakterze dobra moralnego, którego można doświadczyć w działaniu. Wówczas moralność powinności oraz moralność cnoty jawią się jako etapy w procesie moralnego rozwoju nauczyciela. Aby ukazać ów związek, należy najpierw pokrótce przedstawić, w jaki sposób rozwija się cnota.

Czas i miejsce, w których ludzkie władze rozwijają się w kierunku doskonałości cnoty, określane są przez dobry czyn, podejmowany przez człowieka. W czynie poszczególne władze ludzkiej natury wpływają na siebie, a cnota jest możliwa jedynie wówczas, gdy doskonalą się wszystkie wła$\mathrm{dze}^{22}$. Zdobywanie bowiem przez człowieka wiedzy z zakresu etyki nie prowadzi bezpośrednio do jego moralnej sprawności w działaniach, ponieważ w konkretnych sytuacjach różne pobudki skłaniają go do czynów sprzecznych z wiedzą etyczną. Owe pobudki wynikają albo ze specyfiki pożądań nieusprawnionej w kierunku dobra woli, albo z nieuporządkowania sfery pożądań zmysłowych. Czyn, nawet jeżeli jego przedmiotem jest niewielkie dobro przedmiotowe, skutkuje doświadczeniem dobra moralnego. Daje więc tym samym przeżycie radości, szczęścia, związane z działaniem na przykład na rzecz innego człowieka, nieskutkującym egoistyczną przyjemnością, a czasami nawet wymagającym poświęcenia dobra osobistego. Doświadczenie takie, o ile powtarza się, prowadzi do rozwoju rozumu i woli jako władz umysłowych. Z owym doświadczeniem związany jest również proces, który nazywa się sublimowaniem uczuć, a który polega na powiązaniu reakcji władz zmysłowych z decyzjami rozumu i woli - pozytywne emocje pojawiają się w momencie działania niedającego bezpośredniego zadowolenia zmysłowego ${ }^{23}$. W dłuższej perspektywie konsekwencją sublimowania uczuć jest udoskonalenie pożądawczych władz zmysłowych cnotą, co objawia się włączeniem reakcji zmysłowych w działania władz umysłowych. Rozwój cnót kardynalnych: roztropności, sprawiedliwości, umiarkowania oraz męstwa rozpoczyna się zatem od drobnych czynności, podejmowanych na rzecz innego człowieka. Wykonując czyny moralnie dobre, człowiek doskonali się, stając się zdolnym do moralnie dobrych działań o coraz poważniejszej

22 Por. J. Woroniecki, Rozwój osobistości człowieka, w: tenże, Wychowanie człowieka. Pisma wybrane, Kraków 1961, s. 75-77; tenże, Nawyk czy sprawność. Centralne zagadnienie pedagogiki katolickiej, Wilno 1939, s. 18, 26-28; tenże, Studium, s. 229-230; tenże, Paedagogia perennis (Św. Tomasz a pedagogika nowożytna), „Przegląd Teologiczny” 5 (1924), s. 157.

${ }^{23}$ Por. D. Radziszewska-Szczepaniak, Podstawy koncepcji sublimacji uczuć u św. Tomasza z Akwinu, Olsztyn 2002, s. 84-87; M. A. Krąpiec, Psychologia racjonalna, Lublin 1996, s. 125-126; K. Michalski, Duszę dać, w: tenże, Dokad idziemy. Pisma wybrane, Kraków 1964, s. 157-159. 
materii ${ }^{24}$. Niezwykle istotna dla naszkicowanego powyżej procesu jest możliwość doświadczenia moralnej wartości własnych działań. Realizacja dobra przedmiotowego objawia się bowiem w przeżyciach, stymulując kolejne działania i kształtując poszczególne władze człowieka - nie tylko rozum, ale także wolę i władze zmysłowe.

Samo przeżycie jest z kolei możliwe, ponieważ otaczająca człowieka rzeczywistość jest prawdziwa i dobra. Prawda i dobro nie są w tym wypadku rozumiane w sensie podmiotowym - subiektywnym, ale w sensie przedmiotowym - obiektywnym. Takie rozumienie jest związane przede wszystkim z tomistyczną koncepcją transcendentaliów ${ }^{25}$. Jeżeli rzeczywistość, jako prawdziwa i dobra, oddziałuje na człowieka, to zdolny jest on również do doświadczenia moralnej wartości własnych działań w odniesieniu do zewnętrznej rzeczywistości ${ }^{26}$. Należy podkreślić, że przeżyciowy aspekt działań, szczególnie w wymiarze moralnym, został dowartościowany w refleksji fenomenologicznej, a jej osiagnięcia uwzględnił w opisie rozwoju moralnego człowieka Karol Wojtyła. Podsumowując niniejszy wywód, można powiedzieć, że doświadczenie moralnego dobra własnego działania zmienia od wewnątrz działający podmiot, owocując moralnymi cnotami.

W świetle powyższych rozważań przejrzysty staje się związek między etyką powinności i etyką cnoty. Bez względu na to, z jakich pobudek podmiot podejmuje działania moralnie dobre względem podmiotu, owe działania będą odbijały się w przeżyciu, będą stawały się doświadczeniem i w dłuższej perspektywie będą skutkowały kształtowaniem władz zmysłowych i umysłowych działającego podmiotu. Kształtującą moc posiadają zatem także działania podejmowane $\mathrm{w}$ imię podporządkowania deontycznym kodeksom zawodowym albo kształtowane przez etos jakiejś grupy zawodowej. Sumienne spełnianie obowiązków przez nauczyciela może prowadzić do rozwoju cnót, nie tylko podstawowych cnót kardynalnych, ale także cnót moralnych, znaczących w kontekście pracy dydaktycznej i wychowawczej.

Wnioski płynące $\mathrm{z}$ teoretycznych rozważań dobrze korespondują ze stwierdzeniami formułowanymi w wyniku badań empirycznych nad satysfakcją zawodową nauczycieli. Chociaż wykonywanie zawodu nauczyciela łączy się z wieloma problemami, związanymi przede wszystkim z relatyw-

${ }^{24}$ Por. J. Woroniecki, Cnota kardynalna mestwa, s. 236-237.

${ }^{25}$ Por. M. A. Krapiec, Metafizyka - ogólna teoria rzeczywistości, w: M. A. Krapiec, S. Kamiński, Z. J. Zdybicka, A. Maryniarczyk, P. Jaroszyński, Wprowadzenie do filozofii, Lublin 1996, s. 110-111; J. Herbut, Transcendentalia, w: tenże (red.), Leksykon filozofii klasycznej, Lublin 1997, s. 522.

${ }^{26}$ Por. W. Starnawski, Prawda jako zasada wychowania. Podstawy pedagogii personalistycznej w nawiqzaniu do myśli Karola Wojtyly - Jana Pawła II, Warszawa 2008, s. 237-261. 
nie skromnym uposażeniem nauczycieli, to większość nauczycieli przeżywa satysfakcję, której źródłem są głównie efekty pracy dydaktyczno-wychowawczej, a wśród nich (obok wymiernych efektów dydaktycznych) dobry kontakt z uczniami, bycie obdarzonym sympatią i zaufaniem ${ }^{27}$.

Moim zdaniem, charakteryzując rozwój zawodowy nauczyciela, należy uwzględnić te przemiany, które mają wymiar moralny, a dokonują się pod wpływem pozytywnych doświadczeń związanych z pracą dydaktycznowychowawczą. W charakterystyce rozwoju zawodowego nauczyciela wykorzystuje się bowiem zazwyczaj kategorie zapożyczone z teorii rozwoju moralnego L. Kohlberga ${ }^{28}$. Wskazanie na stadia przedkonwencjonalne, konwencjonalne i postkonwencjonalne jest jednak jedynie zewnętrznym opisem procesu, który ma swoją wewnętrzną dynamikę, a wpływają na niego przede wszystkim prawda i dobro, będące nie tyle teorią rozumu, co rzeczywistością, odkrywaną w doświadczeniu i czasami nawet niewyrażoną w formie teorii. Poza tym, charakteryzując stadia konwencjonalne i postkonwencjonalne zwraca się uwagę na uwewnętrznienie norm, które charakterystyczne są dla danej działalności, a tymczasem powyższa refleksja prowadzi do wniosku, że w ramach pracy dydaktycznej i wychowawczej możliwe jest odkrycie dóbr, na które wcześniej nie zwracało się uwagi.

Podsumowując można więc powiedzieć, że trudno spodziewać się od początkującego nauczyciela - bez względu na jego nastawienie względem uczniów - iż będzie charakteryzował się moralnością cnoty. Trudno też przekonywać go do etyki cnoty w ramach uniwersyteckiego wykładu. Rozwój moralności cnoty może dokonać się w procesie rozwoju zawodowego nauczyciela, w miarę jak wspierając swoich podopiecznych w rozwoju, będzie on doświadczał moralnej wartości tych działań. Wniosek ten pokrywa się ze stwierdzeniem Roberta Kwaśnicy, który uważa, że przygotowanie do zawodu nauczycielskiego należy rozumieć procesualnie - jest ono wpisane w rozwój osoby, który nigdy nie ma końca ${ }^{29}$. Oczywiście, możliwa jest również sytuacja przeciwna - nauczyciel nauczy się wykorzystywać do własnych celów przywileje stwarzane przez pracę w szkole i zamiast w kierunku cnót jego władze zostaną usprawnione w kierunku wad. Istnieje także możliwość, że nauczyciel będzie pracował w zawodzie, niezdobywając wewnętrznego przekonania do tej pracy i jego działania pozostaną zawsze jedynie efektem podporządkowania zewnętrznym przepisom. Trudno jednak przewidywać przebieg rozwoju zawodowego osoby podejmującej pracę

27 Por. Z. Kawka, Między misja a frustracja. Społeczna rola nauczyciela, Łódź 1998, S. 109-113.

28 Por. R. Kwaśnica, dz. cyt., s. 305-309; H. Kwiatkowska, Pedeutologia, s. 207-215.

29 Por. R. Kwaśnica, dz. cyt., s. 297. 
nauczyciela. Można jedynie mieć nadzieję, że obiektywne moralne dobro pracy dydaktycznej i wychowawczej będzie powoli kształtowało moralny charakter nauczyciela.

\section{Ethics of Duty vs. Ethics of Virtue in Teacher Training (Summary)}

Given the assumption that a modern teacher's role cannot just be narrowed down to being an instructor, but that he should also carry out the role of a form tutor providing all necessary care, advice, assistance and support for a maturing person, the naturally following question to raise is what ethical attitude a prospective educator should be suggested to adopt towards his occupation as part of a teacher training programme. Two approaches can be singled out in modern studies: the ethics of duty and the ethics of moral virtues. The author makes no attempt at judging either of them nor does he provide an answer to the question, but he tries to indicate the advantages and drawbacks behind the two conceptions. He points out that the ethics of duty, whose nature is object-related, is bound up with the perception of a teaching occupation in terms of professionalism. On the other hand, the ethics of virtue emphasizes subject-related facets of moral actions since its principles lead to understanding of a teaching occupation in terms of vocation. While it can easily be asserted that under the ethics of virtue a greater stress is laid on a teacher's moral excellence, one should notice that such an attitude cannot be inculcated through a series of university lectures because it develops as a lengthy process where personal experience plays a significant role. The dilemma presented in the title can be resolved by stating that both the ethics of duty as well as the ethics of virtue constitute a value which contributes to the professional development of a teacher and affects this process across its successive stages. 